\title{
Analysing the Impact of the 2011 Natural Disasters on the Central Queensland Tourism Industry
}

\author{
Scott Richardson ${ }^{1}$, Roger March², Jan Lewis ${ }^{2} \&$ Kylie Radel $^{2}$ \\ ${ }^{1}$ Blue Mountains International Hotel Management School \&University of Johannesburg \\ ${ }^{2}$ Central Queensland University
}

\begin{abstract}
The past decade has been particularly difficult for the tourism industry worldwide, and in Asia/Australasia in particular, as crises have followed in rapid succession, starting with the terrorist attacks of September 11, 2001. Severe flooding in Central Queensland in early 2011, was followed soon after by Cyclone Yasi, again revealing the vulnerability of communities to the forces of nature. The tourism industry, due to the discretionary nature of the consumption activity, is particularly vulnerable to crises and the fragmented nature of the industry can make it difficult to prepare for and quickly respond to crises. This paper investigates the impacts of the 2011 flooding and Cyclone Yasi on Central Queensland tourism operators and the degree of implementation and effectiveness of the Tourism Queensland Crisis Management Plan Template to prepare regional tourism organisations and businesses for crises such as these. This research has found that whilst only a small number of Central Queensland tourism operators were directly affected by Cyclone Yasi and the flooding, the impacts and outcomes appear very similar for both those directly and indirectly affected: (i) loss of business revenue, downsizing the operation due to the decrease in the number of tourists; (ii) medium term impacts due to ongoing negative media coverage; and (iii)lack of compensation from insurance companies and the Queensland Government. All these have led to a very slow recovery for the tourism industry within Central Queensland.
\end{abstract}

Key words: Tourism industry, crisis management, Central Queensland

Suggested citation: Richardson, S., March, R., Lewis, J. \& Radel, K.(2012). Analysing the impact of the 2011 natural disasters on the Central Queensland tourism industry. TEAM Journal of Hospitality and Tourism, 9(1), 1-14.

\section{Introduction}

Natural disasters are catastrophic events that are likely to outstrip the capacity of societies to manage their impacts. In the Australian state of Queensland, frequent natural disasters are cyclones, floods, storm surges and bush fires. While such events are usually limited in their duration, they are nevertheless events on a scale sufficiently significant to cause governments to substantially and often urgently modify their funding and political priorities. The events can have sizeable and long-term negative impacts on the social, economic and ecological environment in the affected areas (Anderson, 1990).

${ }^{1}$ Correspondence: Scott Richardson; Email: scott.richardson@bluemountains.edu.au 
Severe flooding in Central Queensland in early 2011, followed soon after by Cyclone Yasi, revealed the vulnerability of communities to the forces of nature. The tourism industry, due to the discretionary nature of the consumption activity, is particularly vulnerable to crises and the fragmented nature of the industry can make it difficult to prepare for and quickly respond to crises. The state tourism authority Tourism Queensland (TQ) (2007, p. 4) states that
"Tourism is particularly prone to external shocks, which by their nature are unpredictable and need to be addressed through effective crisis management processes. Across the tourism industry, there are lots of opportunities for 'risks' to turn into 'disasters' or an upheaval event. Issues such as security concerns, natural disasters and outbreaks of infectious diseases have a tremendous impact on the tourism industry. So do incidents as isolated as a bomb threat in an office building in a regional centre, an oil spill in a harbour or on the reef, a mini tornado in an outback town, a train derailment, or a drowning at a beach or on the reef. All of these 'shocks' will have an impact on regional tourism and will require a response from the Regional Tourism Organisation (RTO) and TQ to ensure the least possible disruption to tourism in the region. As such, crisis management and risk assessment have become, and will remain, a vital component of the way all businesses operate within the tourism industry."

The past decade has been particularly difficult for the tourism industry worldwide and in Asia/Australasia in particular, as crises have followed in rapid succession, starting with the terrorist attacks of September 11, 2001. While the allied forces responses, first in Afghanistan in October 2001 and then in Iraq in March 2003, had no direct impact on the tourism industry worldwide, the number of terrorist attacks increased by more than a third (Bergen \& Cruickshank, 2007), leading to increased concerns amongst international travellers.

The tourism industry in Australia was just starting to recover from the effects of September 11, 2001 when a second terrorist attack, this time much closer to home, took place in Bali, Indonesia, in which 202 people, including 88 Australians, were killed. Following the Bali attack, travel in Asia was rocked by the SARS virus outbreak in Hong Kong in 2003, the Avian Flu virus in 2004 and one of the deadliest natural disasters in recorded history, the Indian Ocean Tsunami of December 26, 2004. This disaster killed over 230,000 people in fourteen countries. This was followed by another terrorist attack in Bali in October 2005. In recent years, the tourism industry has been heavily impacted by rising oil prices and the Global Financial Crisis which began in 2007, the remnants of which are still felt today. Recent events have been the terrorist attack in Mumbai, India in 2008 and the Swine Flu pandemic of 2009.

Whilst many of these crises did not directly affect the Central Queensland region, all indirectly impacted tourism in the region. Quite possibly the greatest crisis or risk facing the Central Queensland region is not man-made crises such as terrorism and pandemics but rather natural disasters. In recent years a number of natural disasters have affected the region including severe tropical cyclones, Ingrid and Larry, which crossed the North Queensland Coast in 2005 and 2006 respectively, and also the floods that inundated Mackay in February 2008. In early 2011 the Central Queensland region was impacted by floods affecting Rockhampton, Bundaberg and Emerald, as well as many smaller towns. Shortly after the floods had subsided, the region was hit by Cyclone Yasi, a category five tropical cyclone. 
While the Central Queensland region was largely unaffected by Yasi, the region did suffer from tourist fear of further torrential rain leading to more flooding which did not eventuate.

In the wake of the numerous crises around the world in the past decade, the necessity for tourism operators to have contingency crisis management plans has been emphasised (Blake \& Sinclair, 2003; Carlsen \& Liburd, 2008; Evans \& Elphick, 2005; Faulkner, 2001; Min \& Huang, 2007; Ritchie, 2004; Sönmez, Apostolopoulos \& Tarlow, 1999). A number of authors have found that recovery from an isolated crisis can be achieved in a reasonably short time period. However, prolonged or recurring crises provide tourism operators with a much greater challenge (Carlsen \& Liburd, 2008; Glaesser, 2003). A series of crises in the early to mid-2000s, including the Bali bombings, SARS, Avian Flu and Tropical Cyclone Larry, prompted Tourism Queensland (TQ) to develop a number of strategies to assist regional tourism organisations (RTOs) and tourism operators to be better prepared for future crises. One of the strategies developed by TQ was the 'Regional Tourism Crisis Management Plan Template: A Guide to Preparing a Regional Tourism Crisis Management Plan'(Tourism Queensland, 2007). This was distributed to RTOs in Queensland to facilitate the self-development of regional crisis management plans as well as assist tourism operators to prepare individualised plans. The extent to which the Regional Tourism Crisis Management Plan Template was accepted and implemented by RTOs and local tourism operators is uncertain.

This paper has two principal aims, first to investigate the impacts (e.g., visitation, cancellations, sales, staffing, access) the 2011 floods and Cyclone Yasi had on Central Queensland Tourism operators and second to determine the degree of implementation and effectiveness of the TQ Crisis Management Plan Template to prepare RTOs and businesses for crises such as the floods.

\section{Literature Review}

The tourism sector has proven to be one of the most vulnerable of all industries whereby the effects of any external events or shocks can rapidly spiral into a crisis(Malhotra \&Venkatesh, 2009). Therefore, crisis management in this industry should be viewed as a vital management concern (Evans \& Elphick, 2005). Seymour \& Moore (2000) state that there are two main types of crisis: 'Cobra' and 'Python'. Most crises in the tourism industry fall into the 'Cobra' category whereby the crisis tends to occur in a very short space of time, requiring a rapid response to minimise further damage. The 'Python' type of crisis is more slow to build, and often is due to internal factors such as poor management practices.

Several types of external events can affect a tourist destination negatively. Events, such as natural disasters, economic recessions, epidemics, and international hostilities, precipitate a crisis mainly within the destination. Being well prepared for a crisis does not reduce damage to infrastructure, immediate loss of visitor confidence, or the costs of any post-crisis marketing initiatives; however it can allow for quicker response to, and recovery from, the crises(Seymour $\&$ Moore, 2000). The recent natural disasters in Queensland have had a tremendous impact on the economy. The floods of 2010-11 followed by Cyclone Yasi of 2011 caused a total damage to public infrastructure of between $\$ 5$ and $\$ 6$ billion and major losses to the mining, agriculture, business and retail sectors (PricewaterhouseCoopers, 2011). The extensive media coverage of the Queensland natural disasters added to the spate of cancellations and the estimated loss of revenue for the tourism industry in 2010 - 11 stands at $\$ 590$ million (IBIS World, 2011). 
Certain barriers that affect effective and pre-emptive planning and preparation for a crisis have been identified. Studies have shown that past experiences, size of the business, lack of financial resources, lack of awareness, and lack of accord in the industry, all have a bearing on the planning and preparation efforts put in by tourism organisations (Hystad \& Keller, 2008; Johnston et al., 2007). Environmental factors also greatly contribute to the formation of certain attitudes towards crisis planning. It is also necessary to take into account the social, cultural, economic and political features of the region. Attitudes of tourism organisations and individuals towards crisis planning are influenced by perceptions of the usefulness of such an activity. These perceptions in turn evolve from personal experiences, felt social/organisational pressures, cultural backgrounds and political beliefs (Wang \& Ritchie, 2010).

Three main factors that affect crisis preparedness have been identified: organisation size, management attitude and media. First, Reilly (1987)argues that organisation size seems to have a bearing on the willingness and ability of an organisation to prepare for the management of a potential crisis. Larger organisations appear more inclined to participate in crisis planning activities rather than smaller ones (Wang \& Ritchie, 2010). This might be linked to factors such as availability of resources, specialised departments and better awareness of the benefits of undertaking crisis planning. On the other hand, it is likely that smaller organisations do not perceive the undertaking of crisis planning activities as profitable and hence are less inclined to pursue this activity. Organisation age is another factor that influences the implementation of crisis planning activities, but it does not impact the perceived level of crisis preparedness (Wang \& Ritchie, 2011).

Second, management attitudes towards crisis planning are most often influenced by the positive or negative evaluation of experienced crises. The availability of resources and opportunities to engage in planning activities affects the willingness of management to view crisis planning as a positive endeavour (Rousaki \& Alcott, 2007).

Third, there is a consensus that the media plays a useful role at the pre-event and postevent stages of a crisis (Faulkner, 2001). This especially applies to such events as natural disasters that to some extent are predictable. Valuable information such as warnings and recovery strategies can be distributed to the public. However, the media can also have some negative outcomes such as providing "misleading and contradictory information" (Riley \& Meadows, 1997).

Floods, cyclones and other natural disasters are an inherent part of Queensland's climatic landscape. Their impact on the state's tourism industry has been manifold, creating a financial/ operational crisis for many tourism operators. Recurring natural disasters like floods and cyclones strain the sustainability of the state tourism industry. It is therefore crucial for the tourism industry to adopt a sustainable approach to crisis management. An organisation's ability to react to a crisis situation is directly related to its degree of preparedness for the crisis. To this end, it is beneficial to apply the principles of crisis management (Wang \& Ritchie, 2011).

In 2007, in response to the increasing crises facing the tourism industry, Tourism Queensland created the Regional Tourism Crisis Management Plan Template to assist tourism operators to respond to crises in a planned and co-ordinated manner (Tourism Queensland, 2007). Central to the plan is the pivotal role that RTOs must play in leading and co-ordinating response and recovery initiatives in times of crises (in conjunction with Tourism Queensland and other tourism related organisations). The Regional Tourism Crisis Management Plan Template offers guidelines and strategies for tourism operators to effectively prepare themselves to respond 
to crises(Tourism Queensland, 2007). This study identifies the impacts encountered by tourism operators in the Whitsundays, Mackay, Rockhampton and Bundaberg regions, in respect to the floods crises experienced in December 2010 and January 2011 and Cyclone Yasi in February 2011 as well as their utilisation of the TQ Regional Tourism Crisis Management Plan Template.

\section{Methodology}

To investigate the research aims described above, an online quantitative survey was utilised. The quantitative survey questionnaires were sent to approximately 300 tourism operators in the Central Queensland region. This research focused on three main regions, Bundaberg and Rockhampton, both devastated by the recent (2011) flooding, and Mackay/Whitsundays, heavily affected by flooding in 2008 and also affected by the 2011 floods. The purpose of this survey was to investigate the effect of, and response to, the recent floods, as well as analyse the measures that have been put in place since the 2011 floods to mitigate the effects of future floods, or other crises, in the area. The questions in the survey were a mixture of demographic questions and questions related specifically to the impacts of the crisis on Central Queensland tourism operators developed by the researchers, as well as questions related to crisis management planning derived from a previous study by Wang \& Ritchie (2011). The research encompassed all key sectors of the tourism industry including accommodation providers and resorts, attractions, restaurants, tour operators, and the MICE (Meetings, Incentives, Conferences and Exhibitions) Industry.

The quantitative questionnaire was developed to gather information from a pool of tourism organisations with regard to the impacts of the floods on their businesses. This included gathering information on such issues as crisis management planning, marketing and management response to crises including staffing, cancellation strategies, promotions and collaborative marketing initiatives and impacts of the 2011 floods on the businesses. An email was sent out to approximately 300 tourism businesses in Central Queensland asking them to complete the online survey. These businesses were identified by the four regional tourism organisations (Bundaberg, Rockhampton, Mackay and Whitsundays) as companies with direct links to the tourism industry in the Central Queensland region. A total of 82 completed, usable questionnaires were returned giving a response rate of $27.3 \%$, which compares favourably to other online surveys. The information gathered from this survey was analysed, using SPSS 19.0. For the purposes of this paper only descriptive (frequency) analysis was undertaken.

\section{Results}

\section{Personal Demographics of Respondents}

The first section of the online survey was used to gather demographic information about the participants and their organisations as well as to examine the impacts of the recent flooding such as cancellations, sales, staffing and visitation. The preparedness of the tourism operators for marketing and management response to a crisis such as the recent floods was also examined in this section.

As Table 1 presents, nearly two-thirds (63.4\%) of the respondents were female. It was also noted that more than two-thirds $(70.7 \%)$ of the participants had more than 10 years of experience in the tourism industry with $18 \%$ having more than 30 years of experience in the 
Table 1. Personal demographics

\begin{tabular}{llc}
\hline Variable & Category & Sample $\%$ \\
\hline Gender & Male & 36.6 \\
& Female & 63.4 \\
How many years of tourism industry & Less than 3 years & 3.7 \\
work experience do you have? & $3-5$ & 7.3 \\
& $6-10$ & 18.3 \\
& $11-20$ & 34.1 \\
& $21-30$ & 18.3 \\
What is your current position in the & More than 30 & 18.3 \\
organisation? & Owner & 51.2 \\
& CEO/Managing Director & 8.5 \\
& General Manager & 12.2 \\
& Operator & 7.3 \\
& Operations Manager & 12.2 \\
& Regional/Area Manager & 1.2 \\
& Marketing/Sales Manager & 3.7 \\
& Other & 3.7 \\
\hline
\end{tabular}

Note: $\mathrm{N}=82$.

industry. Only $11 \%$ had less than 5 year's industry work experience with more than $70 \%$ being the owner, CEO or General Manager of the company. These findings highlight that the survey was completed by people with extensive tourism industry experience and knowledge.

\section{Organisation Demographics}

Table 2 shows that more than half $(56.1 \%)$ of the participating organisations had been operating in the tourism industry for more than 10 years with $14.6 \%$ of the organisations having more than 30 years industry experience. Research has shown that almost $70 \%$ of tourism and hospitality businesses in Australia (National Tourism Investment Strategy Consultative Group, 2006) have fewer than 5 employees. The Tourism Division (2002) also states that up to $90 \%$ of tourism operators and providers in Australia employ less than 20 people. The House of Representatives Standing Committee on Employment, Workplace Relations and Workforce Participation (2007) agrees, stating that more than $88 \%$ of tourism businesses in the café, restaurant and accommodation sector, and $95 \%$ in the cultural and recreational service sector have fewer than twenty employees. This Standing Committee states that only $2.5 \%$ of tourism businesses employ more than one hundred staff, with large hotels and resorts making up most of these businesses. These smaller businesses are commonly referred to as small and medium enterprises (SMEs). The size of the organisations represented in this study reflect the overall structure of the industry with $92.7 \%$ of organisations being classed as SMEs as they employ less than 50 staff. Table 2 also shows that $44 \%$ of the organisations were in the accommodation sector of the industry and $15.8 \%$ were operating cafes or restaurants. Again, this is reflective of the overall industry with the Australian Bureau of Statistics (ABS, 2008) stating that the largest employer in the tourism industry was the accommodation sector followed by cafés and restaurants. 
Table 2. Organisation demographics

\begin{tabular}{llc}
\hline Variable & Category & Sample \% \\
\hline How long has your organisation been & Less than 3 years & 14.6 \\
operating in the tourism sector? & $3-5$ & 7.3 \\
& $6-10$ & 22.0 \\
& $11-20$ & 29.3 \\
& $21-30$ & 12.2 \\
& More than 30 & 14.6 \\
How many persons are currently & Less than 5 & 52.4 \\
employed by your organisation? & $5-10$ & 29.3 \\
& $11-20$ & 7.3 \\
& $21-50$ & 3.7 \\
& More than 50 & 7.3 \\
Which category best describes your & Accommodation & 44.0 \\
tourism business? & Cafes/Restaurants & 15.8 \\
& Air Transport & 3.7 \\
& Water Transport & 1.2 \\
& Marine-based Operator & 7.3 \\
& Land-based Operator & 9.8 \\
& Cultural Services & 1.2 \\
& Sport and Recreation & 8.5 \\
& Retail & 8.5 \\
\hline
\end{tabular}

Note: $\mathrm{N}=82$

\section{Managing a Crisis}

The next section of the survey (Table 3), started by asking respondents whether they had ever experienced a crisis in the tourism industry and, if so, were they personally involved in managing and responding to the crisis. More than two-thirds (67.1\%) responded that they had experienced an actual crisis in the tourism industry and $95.5 \%$ of them indicated that they have been personally involved in managing the crisis. When asked whether their organisation was prepared to cope with a crisis, $70.8 \%$ claimed they were prepared with only $25.6 \%$ stating they were not prepared. The respondents were then asked about Tourism Queensland's Regional Tourism Crisis Management Plan Template. The vast majority (89\%) stated that they had no information about the template prior to the floods. Of the 9 respondents who had knowledge of the template, all stated that they found the information in the template useful.

\section{Impact of the 2011 Floods on Central Queensland Tourism Operators}

The next section of the survey analysed the impact of the crisis on tourism operators such as financial effects, cancellations, sales and staffing changes. The results of these questions are presented in Tables 4, 5, and 6. Table 4 shows that more than most $(89 \%)$ of the respondents responded that their organisation lost business income that they would normally expect for that time of the year. When asked about the percentage of business income loss from the normal expected income, almost one-third $(31.5 \%)$ of the respondents stated that there was 
Table 3. Managing crisis $(\mathrm{N}=82)$

\begin{tabular}{llc}
\hline Variable & Category & Sample \% \\
\hline Have you ever experienced a crisis in & Yes potential & 14.6 \\
the tourism industry? & Yes actual & 67.1 \\
& No & 18.3 \\
& Yes & 95.5 \\
Have you personally been involved in & No & 4.5 \\
managing and responding to the & & \\
crisis? (N=55) & Strongly Disagree & 3.6 \\
Our organisation is prepared to cope & Moderately Disagree & 11.0 \\
with a crisis? & Slightly Disagree & 11.0 \\
& Neutral & 3.6 \\
& Slightly Agree & 23.2 \\
& Moderately Agree & 22.0 \\
& Strongly Agree & 25.6 \\
& Yes & 11.0 \\
Did you have any information & No & 89.0 \\
about the TQ RTCM Plan Template & & 100.0 \\
prior to the floods? & Yes & - \\
Did you find the information in & No & \\
the template useful? &
\end{tabular}

Table 4. Impacts of 2011 floods $(\mathrm{N}=82)$

\begin{tabular}{|c|c|c|}
\hline Variable & Category & Sample $\%$ \\
\hline $\begin{array}{l}\text { Did your organisation lose business income that you would } \\
\text { normally expect for that time of the year? }\end{array}$ & $\begin{array}{l}\text { Yes } \\
\text { No }\end{array}$ & $\begin{array}{l}89.0 \\
11.0\end{array}$ \\
\hline $\begin{array}{l}\text { Approximately what was the } \% \text { of business income loss } \\
\text { from what you would normally expect for that period of } \\
\text { summer season trading? }\end{array}$ & $\begin{array}{l}0-15 \\
16-30 \\
31-50 \\
51-65 \\
66-90 \\
91-100\end{array}$ & $\begin{array}{c}- \\
41.1 \\
31.5 \\
11.0 \\
16.4 \\
-\end{array}$ \\
\hline Our organisation was forced to reduce operational costs. & $\begin{array}{l}\text { Yes } \\
\text { No }\end{array}$ & $\begin{array}{l}74.4 \\
25.6\end{array}$ \\
\hline By what percentage did you reduce costs? & $\begin{array}{l}\text { Less than } 10 \\
10-20 \\
21-30 \\
31-40 \\
\text { More than } 40\end{array}$ & $\begin{array}{l}11.5 \\
14.8 \\
14.8 \\
39.3 \\
19.6\end{array}$ \\
\hline Our organisation increased our marketing efforts. & $\begin{array}{l}\text { Yes } \\
\text { No }\end{array}$ & $\begin{array}{l}56.1 \\
43.9\end{array}$ \\
\hline $\begin{array}{l}\text { How much extra did you spend on marketing as a result } \\
\text { of the flooding in December 2010/January 2011? }\end{array}$ & $\begin{array}{l}\text { Less than } \$ 1,000 \\
\$ 1,001-\$ 3,000 \\
\$ 3,001-\$ 5,000 \\
\$ 5,001-\$ 10,000 \\
\text { More than } \$ 10,000\end{array}$ & $\begin{array}{r}37.0 \\
21.7 \\
21.7 \\
6.5 \\
13.1\end{array}$ \\
\hline
\end{tabular}


Table 5. Impact of 2011 floods $(N=82)$

\begin{tabular}{llc}
\hline Variable & Category & Sample $\%$ \\
\hline Our organisation received cancellations. & Yes & 75.6 \\
How many cancellations did you receive? & No & 24.4 \\
& Less than $10 \%$ & 41.5 \\
& $10-30 \%$ & 27.7 \\
Did you charge a cancellation fee to bookings that were cancelled? & $31-50 \%$ & 27.7 \\
Our organisation was forced to make some staff redundant. & More than 50\% & 3.1 \\
& No & - \\
How many staff were made redundant? & Yes & 100.0 \\
& No & 25.6 \\
Our organisation reduced the number of hours worked by casual & $1-2$ & 74.4 \\
and part-time staff. & $3-4$ & 85.7 \\
On average, each casual and part-time staff hours were reduced by & Yes & - \\
& No & - \\
& $1-2$ & - \\
& $3-4$ & 14.3 \\
& More than 10 & 36.4 \\
& $5-6$ & 5.8 \\
\hline
\end{tabular}

a $31-50 \%$ loss and $41.1 \%$ stated that the loss was $15-30 \%$. More than one quarter $(27.4 \%)$ of the respondents stated that their loss of income was greater than $50 \%$.

The respondents were next asked about the financial effects that were indirectly incurred as an impact of the floods. Almost three-quarters (74.4\%) of the respondents stated that their organisation was forced to reduce operational costs with more than half $(58.9 \%)$ stating that operational costs were cut by more than $30 \%$. When examining the effect on marketing strategies, more than half $(56.1 \%)$ of the respondents noted that their organisation increased their marketing efforts. Of the 46 respondents who had increased their marketing efforts in an attempt to combat the impacts of the floods, nine said that they had spent an extra $\$ 5,000$ in marketing.

Table 5 indicates the results on the issue of cancellations during the floods. More than three-quarters $(75.6 \%)$ of the respondents indicated that their organisation received cancellations with $30.8 \%$ responding that more than $30 \%$ of their bookings were cancelled. All the respondents stated that they did not charge a cancellation fee to the bookings that were cancelled. The respondents were then asked about the impact of the floods on their staffing levels. More than one-quarter $(25.6 \%)$ of the respondents stated that their organisation was forced to make some staff redundant with the majority of those $(85.7 \%)$ indicating that $1-2$ staff were made redundant, whilst three organisations $(14.3 \%)$ stated that they were forced to make more than 10 staff redundant. Almost two-thirds (63.4\%) of respondents also stated that their organisation reduced the number of hours worked by casual and part time staff. More than one quarter $(28.8 \%)$ of those who indicated reduction in working hours specified that 
Table 6. Impact of 2011 floods $(\mathrm{N}=82)$

\begin{tabular}{|c|c|c|}
\hline Variable & Category & Sample $\%$ \\
\hline $\begin{array}{l}\text { Did your organisation access any disaster relief funding from } \\
\text { state or federal departments? }\end{array}$ & $\begin{array}{l}\text { Yes } \\
\text { No }\end{array}$ & $\begin{array}{l}11.0 \\
89.0\end{array}$ \\
\hline $\begin{array}{l}\text { From which government department did you receive disaster } \\
\text { relief funding? }\end{array}$ & $\begin{array}{l}\text { Centrelink } \\
\text { Disaster relief fund } \\
\text { Tourism QLD }\end{array}$ & $\begin{array}{l}33.3 \\
33.3 \\
33.3\end{array}$ \\
\hline How much relief funding did you receive? & $\begin{array}{l}\text { Less than } \$ 1,000 \\
\$ 1,001-\$ 3,000 \\
\$ 3,001-\$ 5,000 \\
\$ 5,001-\$ 10,000 \\
\text { More than } \$ 10,000\end{array}$ & $\begin{array}{c}- \\
66.7 \\
33.3 \\
- \\
-\end{array}$ \\
\hline $\begin{array}{l}\text { Was your business covered by any insurance policy against } \\
\text { floods and or natural disasters? }\end{array}$ & $\begin{array}{l}\text { Yes } \\
\text { No }\end{array}$ & $\begin{array}{l}52.4 \\
47.6\end{array}$ \\
\hline $\begin{array}{l}\text { Was your organisation able to successfully make a claim } \\
\text { out of your policy? }\end{array}$ & $\begin{array}{l}\text { Yes } \\
\text { No }\end{array}$ & $\begin{array}{l}20.9 \\
79.1\end{array}$ \\
\hline How much were you able to claim? & $\begin{array}{l}\text { Less than } \$ 1,000 \\
\$ 1,001-\$ 3,000 \\
\$ 3,001-\$ 5,000 \\
\$ 5,001-\$ 10,000 \\
\text { More than } \$ 10,000\end{array}$ & $\begin{array}{c}- \\
22.2 \\
11.1 \\
- \\
66.7\end{array}$ \\
\hline Our organisation postponed new investments. & $\begin{array}{l}\text { Yes } \\
\text { No }\end{array}$ & $\begin{array}{l}63.4 \\
36.6\end{array}$ \\
\hline $\begin{array}{l}\text { Our organisation prepared new or amended existing } \\
\text { crisis management plans }\end{array}$ & $\begin{array}{l}\text { Yes } \\
\text { No }\end{array}$ & $\begin{array}{l}54.9 \\
45.1\end{array}$ \\
\hline
\end{tabular}

the average hours reduced were more than 10 hours per week, whilst $48.1 \%$ stated that working hours were reduced by 5-10 hours.

The participants were then asked about any relief funding from government departments they received to help mitigate the impacts of the floods or cyclone. Table 6 shows $89 \%$ of the respondents stated that their organisation did not receive any disaster relief funding from state or federal departments. Among the 9 organisations which received government funding, onethird (33.3\%) indicated that they received financial assistance from Centrelink, the Australian Government welfare agency, one-third (33.3\%) from the Queensland Governments Disaster Relief Fund and the final third (33.3\%) from Tourism Queensland. Two thirds $(66.7 \%)$ of those who received government funding were provided financial assistance ranging from $\$ 1001$ to $\$ 3000$ and one-third (33.3\%) received between $\$ 3001$ and $\$ 5000$. The respondents were then asked about the insurance coverage for their organisations and proceedings they received from insurance claims. Slightly more than half $(52.4 \%)$ of the participants stated that their business was covered by an insurance policy against floods and/or natural disasters while $47.6 \%$ stated their business was not covered. More than three-quarters $(79.1 \%)$ of the respondents who indicated insurance policy coverage for floods claimed that their organisation was not successful in making a claim out of their policy. Among those who indicated that their business received claim proceeds from their insurance policy, two-thirds $(66.7 \%)$ stated that 
they received more than $\$ 10,000$. Table 6 also show that almost two-thirds $(63.4 \%)$ of the respondents stated that their organisation postponed new investments and more than half $(54.9 \%)$ of the respondents indicated that their organisation prepared new or amended existing crisis management plans.

\section{Discussion and Recommendations}

As indicated previously, this paper has two principal aims, firstly to investigate the impacts (e.g., visitation, cancellations, sales, staffing, access) of the 2011 floods and Cyclone Yasi on Central Queensland Tourism operators and to determine the degree of implementation and effectiveness of the TQ Crisis Management Plan Template to prepare RTOs and businesses for crises. While the impact of the widespread flooding and Cyclone Yasi on the Central Queensland region was quite short in nature, the long term impact has been devastating to the tourism industry in the region. At the time this research was conducted, six months following Cyclone Yasi, many tourism operators were still in the long term/recovery stage and had not yet moved to the resolution stage of business as usual (Ritchie, 2004). The message that all of Queensland is open to tourism seems to have been lost on some tourists. The message portrayed in the popular media that all tourism in Queensland had closed due to the flooding and Cyclone Yasi was false, as many tourism operators were only indirectly affected and were still operating. To minimise the negative impacts of the media in these cases it is recommended that the regional tourism organisations as well as Tourism Queensland play a greater role in the dissemination of information to the media and customers to ensure the correct message is being received.

The flooding and Cyclone Yasi created immediate issues for tourism operators such as cancellations of bookings and the need for staff redundancy or the need to decrease the number of hours worked by employees. However, the medium- to long-term impacts were perhaps just as devastating as the impacts of the crises were felt for many months. For those tourism enterprises that were directly affected, $52 \%$ had insurance cover for the event but importantly, 79\% could not make a claim against their insurance company. Those fortunate operators who were able to make a claim were also able to obtain more than $\$ 10,000$ and this was generally those businesses that faced actual physical damage to their property as a result of the crises. Government funding to assist tourism operators after the crises was also lacking as $89 \%$ of respondents did not receive any financial support from government agencies and those that did, all received less than $\$ 5,000$. The main reason for this lack of funding is related to the fact that many organisations did not have any physical damage to their property; in fact many were not directly affected by the flooding at all. It is suggested that government agencies need to consider the economic impact as well as physical impacts of these types of crises when determining funding criteria.

As previously indicated, one of the key factors affecting the capacity of tourism organisations to manage and recover from crises is the size of the organisation. As demonstrated by the findings of this study, the majority of businesses in these regions are small to medium enterprises of less than 50 staff. As indicated by the literature, it is typically large enterprises that have the human and financial resources to devote to crisis planning and management strategies. However, with over $81.7 \%$ of the participant organisations in the Central Queensland region employing less than $10 \mathrm{staff}$, it demonstrates the significant challenges that these enterprises have in attending to disaster planning and crisis management. It is evident from this research 
that these tourism operators lacked both the human and financial resources to prepare for and respond to the crisis and therefore, suffered large losses.

Tourism Queensland is aware of the issues related to resource constraints for small to medium tourism organisations and this is one of the main reasons that the Tourism Queensland regional Tourism Crisis Management Plan Template was developed. However this research has found that the majority of respondents to the survey indicated they had not known of the template prior to the crisis nor used it. While over $50 \%$ of respondents also indicated they had (or would) prepare(d) new or amended crisis plans for the next disaster, many of these operators are still doing so without the benefit of the resources and information provided by the crisis management template. This in turn, indicates that Tourism Queensland's post-crises promotions program needs to also include promotion of the template to operators as much as it needs to promote that Queensland is indeed open for business. It is to be noted that these types of crises can have long-term negative impacts on tourism businesses if not managed correctly. The tourism businesses in Central Queensland need to make more efforts to prepare crisis management plans despite the limitations they face.

\section{Conclusion}

This research has found that whilst only a small number of Central Queensland Tourism operators were directly affected by Cyclone Yasi and the flooding, the impacts and outcomes appear very similar for both those directly and indirectly affected. Loss of business revenue, downsizing the operation due to the decrease in number of tourists, medium term impacts due to ongoing negative media coverage, and lack of compensation from insurance companies and the Queensland Government has led to a very slow recovery for the tourism industry within Central Queensland.

A number of other critical points were found. Where operators had undertaken the 'Weatherproofing your business' training, they found it valuable and the workshop approach provided tangible outcomes for them to implement in their business. However, there is a need for further development to deliver this training through different media and at different times and locations to ensure that 'time poor' operators benefit. A number of critical issues arose as a result of applying the crisis management framework, which needs to be addressed. The framework highlighted that the pre-event and prodromal stages were well managed. However, the intermediate and long-term recovery stages need much greater focus to develop strategies for implementation to continue both product redevelopment and marketing communication strategies up to six months to one year after the events. This activity is required to ensure that negative images generated during the events is minimised as quickly as possible.

With regard to product and infrastructure redevelopment, further investigation needs to occur around the criteria for deployment and use of government funding to assist both the directly and indirectly affected businesses. Finally, attention needs to be drawn to the cumulative nature of crisis events and the often hidden reality for operators where successive small, unrelated crises can result in an overall effect similar to a significant terrorism event. This accumulation of negative activities has previously been unrecognised and has therefore not been addressed in government or operator crisis planning. 


\section{References}

ABS. (2008). 6202.0 - Labour force. (6202.0). Canberra: ABS. Retrieved 18 November 2009 from: http:// www.ausstats.abs.gov.au/ausstats/subscriber.nsf/0/4A70C49E4AC5A436CA2574 9D0015322E/\$File/62020_jul 2008.pdf.

Anderson, M. (1990). Analyzing the costs and benefits of natural disaster responses in the context of development. Environment Working Paper 29. Washington, DC: World Bank.

Bergen, B. \& Cruickshank, P. (2007). The Iraq effect: War has increased terrorism sevenfold worldwide. Mother Jones, March/April. Retrieved 15 February 2011 from: bttp:/ / www.truthout.org/article/ the-iraq-effect-war-has-increased-terrorism-sevenfold-worldwide

Blake, A. \& Sinclair, M. T. (2003). Tourism crisis management: US response to September 11. Annals of Tourism Research, 30(4), 813-832.

Carlsen, J. C. \& Liburd, J. J. (2008). Developing a research agenda for tourism crisis management, market recovery and communications. Journal of Travel \& Tourism Marketing, 23(2), 265276.

Evans, N. \& Elphick, S. (2005). Models of crisis management: An evaluation of their value for strategic planning in the international travel industry. International Journal of Tourism Research, 7(3), 135-150.

Faulkner, B. (2001). Towards a framework for tourism disaster management. Tourism Management 22(2), 135-147.

Glaesser, D. 2003. Crisis management in the tourism industry. Oxford: Butterworth Heinemann.

House of Representatives Standing Committee on Employment Workplace Relations and Workforce Participation. (2007). Current vacancies: Workforce challenges facing the Australian tourism sector. Canberra. Retrieved 4 May 2008 from: http:// www.aph.gov.au/ house/committee/ ewrwp/tourism/ report/fullreport.pdf.

Hystad, P. W. \& Keller, P. C. (2008). Towards a destination tourism disaster management framework: long term lessons from a forest fire disaster. Tourism Management, 29(1), 151162.

IBIS World. (2011). Queensland floods: The economic impact. Brisbane: Retrieved 11 July 2012 from http:// www.ibisworld.com.au/common/pdf/QLD floods special report.pdf.

Johnston, D., Becker, J., Gregg, C., Houghton, B., Paton, D., Leonard, G. \& Garside, R. (2007). Developing disaster warning and response capacity in the tourism sector in coastal Washington, USA. Disaster Prevention and Management, 16(2), 210-216.

Malhotra, R. \& Venkatesh, U. (2009). Pre-crisis period planning: Lessons for hospitality and tourism. Worldwide Hospitality and Tourism Themes 1(1), 66-74.

Min, J. C. H. \& Huang, T. F. (2007). Strategies for inbound tourism recovery from a catastrophe: The case of severe acute respiratory syndrome in Taiwan Contemporary Management Research 3(3), 253-266.

National Tourism Investment Strategy Consultative Group (2006). In Department of Industry, Tourism and Resources (Ed.), Chapter 10: Work-force and training (pp. 63-70). National Tourism Investment Strategy: Investing for our future, Canberra.

PricewaterhouseCoopers. (2011). Economic impact of Queensland's natural disasters. Brisbane. Retrieved 11 July 2012 from: http:/ / www.pwc.com.au/about-us/flood-support/assets/EconomicImpact-Qld-Natural-Disasters.pdf. 
Reilly, A. H. (1987). Are organisations ready for crisis? A managerial scorecard. Journal of World Business 22(1), 79-88.

Riley, J. \& Meadows, J. (1997). The role of information in disaster planning: A case study approach. Disaster Prevention and Management 6(5), 349-355.

Ritchie, B. W. (2004). Chaos, crises and disasters: a strategic approach to crisis management in the tourism industry. Tourism Management 25(6), 669-683.

Rousaki, B. \& Alcott, P. (2007). Exploring the crisis readiness perceptions of hotel managers in the UK. Tourism \& Hospitality Research, 7(1), 27-38.

Seymour, M. \& Moore, S. (2000). Effective crisis management: Worldwide principles and practice. London: Cassell.

Sönmez, S., Apostolopoulos, Y. \& Tarlow, P. (1999). Tourism in crisis: Managing the effects of terrorism. Journal of Travel Research, 38(1), 13-18.

Tourism Division (2002). Research Report Number 4: Tourism Workforce and Training. Retrieved 12 April 2006 from: Department of Industry, Tourism and Resources (DITR) bttp:/ / www.industry.gov.au/ assets/ documents/itrinternet/4.ResearchReportNo4TourismWorkforce andTraining20050202121253.pdf

Tourism Queensland. (2007). Regional Tourism Crisis Management Plan Template: A Guide to Preparing a Regional Tourism Crisis Management Plan. Brisbane: Tourism Queensland.

Wang, J. \& Ritchie, B. W. (2010). A theoretical model for strategic crisis planning: factors influencing crisis planning in the hotel industry. International Journal of Tourism Policy, 3(4), 297-317.

Wang, J. \& Ritchie, B. W. (2011). Are organisations prepared for a crisis? An evaluation of crisis planning in the accomodation industry in Australia. Paper presented at the CAUTHE 2011 National Conference, Adelaide. 